\title{
HUMANISTIC ASPECTS OF PROJECT MANAGEMENT
}

\author{
Aldona MUSIAŁ-KIDAWA \\ Silesian University of Technology, Faculty of Organization and Management; aldona.musial-kidawa@polsl.pl, \\ ORCID: 0000-0001-9525-6348
}

Purpose: The paper takes up the problem of project management from a historicalphilosophical perspective.

Methodology: The main method is a critical analysis of literature on the subject.

Findings: The article draws attention to the mechanism for creating new methods of project management.

Social implications: The paper discusses the evolution from an unconscious form of performing unique activities each time requiring planning and detailed preparation to a strict scientific method using a complex mathematical apparatus.

Originality/value: A new way of approaching the subject is combining aspects of philosophy with the social function of management.

Keywords: management, design, arts and crafts.

Category of the paper: Conceptual paper, General review.

\section{Introduction}

The subject of the article will be to consider the essence of the project in its broadest sense and activities related to its management. The article presents the project as an undertaking accompanying human activity since the beginning of time. Human activity in this area is inextricably linked to the functioning of man as an economic being, conducting a wide range of economic activities, from collecting and hunting to farming and breeding. The concept of such a defined economic activity also extends to its early human forms and includes higher animal forms, such as the a group of higher primates, and this is especially important as "knowing the historical context of management gives a sense of continuity of the historical heritage of this field of science and business practice" (Beliczyński J., 2011).

All these groups have taken or are taking actions which at least in part relate to the definition of the project and undertake specific activities involving project management. Project management should therefore be understood as a set of activities related to the achievement of 
the objective of the project based on the methods developed in practice. The scientific community agrees in principle on the general definition of a project, with definitions varying only in detail. All projects can be assigned the following general characteristics:

- a temporary organisation, i.e. a team of people delegated to implement a specific project,

- a unique venture of varying degrees of complexity,

- a defined objective, defined in time, with a distinguished beginning and end,

- the required commitment of limited resources, both human and material and financial,

- usually carried out by a team of specialists from various fields, although there are projects carried out by one person,

- usually associated with high economic risk, requiring the use of unusual preparation and implementation methods.

The definition given by the Project Management Institute PMI defines a project as: "temporary project aimed at creating a unique product or service, where temporariness means that the project has a well-defined beginning and end, and uniqueness means that the product or service is clearly different from all similar products or services" (Pietras, Shmit, 2003). Project management, on the other hand, is according to PMI: "process by which the project leader carries out targeted planning and control of the tasks of the project and allocates the resources allocated to the project using appropriate techniques and methods to achieve the intended purpose within a specified period, at a specified cost and quality" (Pietras, Szmit, 2003). Thus, a project is unique, individual, unique, defined in concrete outlines, with a clearly defined objective. The project has an objective aimed at the expected change. The realization of a project is usually a team effort, although, for example, an artistic work can be done by one artist.

\section{Historical conditions of project management}

Since time immemorial, people have undertaken activities that can be treated as projects. The project was a mammoth hunt. It was necessary to plan the campaign, gather a specific team of specialists, and the necessary equipment and manage the risk, including anticipating the economic aspects of the expedition, sometimes lasting many days.

A project was a trip for a fire described in Jean-Jacques Annaud's 1981 Oscar-winning film adaptation entitled "Quest for Fire". The protagonists of the story set off on a long journey, marked by many dangers, in search of the fire desired by the community. The project meets all the above-mentioned characteristics. It is unique with a complexity that is difficult to define. It has a beginning and a defined end, requires the commitment of limited resources, both human and material. It is carried out by a team of specialists and is associated with a high risk of loss, both in people and equipment. It requires methods of implementation unknown so far. 
The expedition has a clearly defined objective, has been meticulously planned and prepared logistically and the technical means have been secured. The success of a project depends as much on the intelligence and perseverance of the team as on undefined factors such as intuition or happiness.

The issue of project management escapes the usual methods and schemes and is therefore closer to art. It is not without a reason that whole areas of activity bearing the traits of projects were called arts, such as martial arts, construction art, or medical art. A project also bears the hallmarks of the creation of the world, as described in the Biblical Book of Genesis. According to the accounts of the authors of the book, the creator behaves like a project manager. First, he plans its undertaking, defining resources and setting the time horizon. He then carries out the project, controlling its execution at each stage and approving the subsequent stages with a statement that they have been done well.

An issue that undoubtedly belongs to the group of projects is the implementation of Ulysses' return to Ithaca after the end of the ten-year Trojan War, presented in Homer's Odyssey. The King of Ithaca has a specific purpose and considerable resources. He has a team of associates. He is planning a project. He also knows the risks involved. The project poses many problems at every stage of its implementation. These problems require a dynamic and effective solution. Despite many difficulties, the project ends up achieving its goal.

A project was also undertaken by Tales of Milet, the first philosopher of the pre-Socratic period, a representative of the Ionian philosophy of nature. Tales is widely regarded as the first philosopher and mathematician of Western civilization. It is assumed that he was the first to study reality by referring to nature and reason, and not, as was commonly done, to the will of the gods. His project was to lease the oil mill in a year of abundant olive harvests, which allowed Tales to achieve a high material standing. Diogenes Laertios mentions this event in his work, writing: "Hieronim of Rhodes in the second book of his Historical Notes says that Tales, wanting to show how easy it is to get rich when he predicted an abundant harvest of olives, leased the olive presses and thus made a large fortune" (Diogenes Laertios, 2005).

Projects can be described as battles conducted by ancient tribes, but also wars conducted by whole nations. Finally, a project can be a culinary activity while frying pancakes or preparing dough with fruit (Pietras, Szmit, 2003).

Project-related issues were dealt with by successive thinkers of ancient Greece, analysing the processes occurring in the management of Greek policies, the execution of crafts and finally farm management, (Collinson, 1997).

Xenofont, one of Socrates' students, the author of the work entitled „Oikonomikos”, describes the processes of farm management, giving proposals of solutions aimed at achieving beneficial effects from land management (Małecki-Tepicht, 2014). Plato, on the other hand, treated the pursuit craft activity in terms of art (techne). In "Dialogues" he refers to medicine or sailing as "techne". For Plato, "techne" is not a form of production (poiesis), but cognition (gnosis). Thus "techne" leads to knowledge (episteme). The separation of "techne" and 
"poiesis" is in line with the contemporary understanding of the project as a one-off, exceptional and unique act, independent of production, which is a multiple and repetitive proces (Maliński, 2015).

It is no coincidence that the implementation of projects has been treated for centuries in terms of art. Projects are unique and therefore require a great deal of imagination, intuition and expertise. Cathedral builders associated with Masonic associations passed their expertise onto their sons as secret knowledge. Only a few could be allowed to know these secrets. This is the same way one used to work in stone, sculpture and painting workshops. Each work was a separate project and required slightly different management. A master craftsman was a true engineer according to the etymology of the word. The word engineer comes from the French "ingénieur", i.e. a man of creative mind, inventor, constructor in the sense of design and contractor in one (Sobczak, 2017). To this day, such a half artistic and technical profession is that of an architect. Great construction projects in ancient times were the construction of the pyramids in Egypt, the erection of temples in Greece: Parthenon with the statue of Athena in Athens, the Temple of Zeus with the statue of the Olympic Zeus in Olympia. „Reflections on how to act in an organized way were continued by thinkers and philosophers of the Middle Ages and modern times, as well as from the 16th to 19th century by economists, mathematicians, practitioners and industrialists. There is no doubt that ancient times also provided a solid basis for the emergence of (at the turn of the 19th and 20th century) management as an independent scientific discipline" (Beliczyński, 2011). Today, project management is a compendium of knowledge resulting from accumulated experience from past times and its use to create and set new directions of development. Polish achievements in this field are also significant. Polish engineers have made a huge contribution to the development of this field of knowledge. Below are just a few names from a huge group of Polish engineers implementing large projects on all continents (Piłatowicz, 2001):

- Grzegorz Bekker Mieczysław (1905-1989), pioneer of terramatic studies, vehicleterrain science. Co-creator of the Lunar Roving Vehicle in the Apollo 15, 16 and 17 programmes.

- Stefan Bryła (1886-1943), pioneer in the welding of steel structures and the use of welding in construction. He built the first electrically welded bridge in Europe on the Słudwia River near Łowicz.

- Stanisław Gzowski Kazimierz (1813-1898), civil engineer, pioneer of railway construction in Canada. In 1870-73 he built the International Bridge, the longest bridge over the Niagara River in North America (1100 m) with a middle swing, connecting Fort Erie in Canada with Buffalo in the United States.

- Adam Malinowski (1818-1899), construction engineer, creator of the highest railway in the Peruvian Andes 1870-1893.

- Rudolf Modrzejewski (1861-1940), engineer, builder of large steel bridges in the United States of America, pioneer of modern hanging Bridges. 
- Stanisław Rogalski (1904-1976), Wigura Stanisław (1903-1932), Drzewiecki Jerzy (1902-1990), mechanical engineers, constructors of the famous Polish RWD sports aircraft.

- Franciszek Sokulski (1811-1893 or 1896), military engineer, insurgent, emigration activist, pioneer of telegraphic network construction in the Turkish Empire.

- Jan Szczepanik (1872-1926), inventor in the field of colour photographs and films, precursor of television and modern tapestry weaving.

- Tadeusz Wenda (1863-1948), creator of the concept and builder of the sea port in Gdynia.

- Piotr Wilniewczyc (1887-1960), eminent weapon designer, co-creator of "ViS" and "MORS", pistols, creator of "WiR" and "RAK" pistols.

- Mieczysław Wolfke (1883-1947), developed the principles of television and holography, solidified helium under pressure.

- Sanisław Wysocki (1805-1868), chief engineer of the Bank of Poland, creator of the Warsaw-Vienna Iron Road, pioneer of asphalt pavements.

- Stanisław Zwierzchowski (1880-1940), creator of innovative water turbine designs in the United States

\section{Modern project management}

Project management methods as an engineering art, having their own methodology, started to crystallise only in recent times. The ideas and solutions contained in the works of Karol Adamiecki concerning scheduling (Adamiecki, 1938) or Henry Gantt - Gantt Diagram (HarperSmith, Derry, 2012) continue to be used, but the Manhattan Engineering Districk Project from 1940 , aimed at creating weapons of great power of destruction, is considered to be the beginning of the scientific approach to project management, for which a special project structure was created. The culmination of this project was the construction of the atomic bomb. The project was carried out in the Los Alamos National Laboratory, with the cooperation of three American academic centres and many outstanding scientists, including current and future Nobel Prize winners.

The more important projects that shaped project management methods are presented below (Tracki, Grucza, Ogonek, 2003):

The 1940s. - Manhattan Engineering Districk Project (atomic bomb).

The 1950s. - Color TV (USA).

The 1960s. - Apollo Programme (NASA); Solaris Programme (US Navy).

The 1970s. - Ariene Missile Programme; Tornado Fighter; SNR Reactor. 
The 1980s. - IBM Personal Computer; Airbus A320.

The 1990s. - Jager 90; Spacelab.

Civilian projects using project management methods are related to the American aid programmes for Europe, the so-called Marshall Plan. The following years brought the development of network methods for projects:

CPM - Critical Path Method, 1957.

PERT - Program Evaluation and Review Technique, 1958.

MPM - Metro Potential Method, 1958.

GAN - Generalized Activity Network, 1962.

PDM - Precedence Diagramming Method, 1964.

GERT - Graphical Evaluation and Review Technique, 1966.

The theoretical approach to project management dates back to the second half of the last century with the publication of John Stanley Baumgartner's book "Project Management" in 1963. The breakthrough is considered to be the release of a series of publications by the U.S. Air Force in 1966 containing experience in project management, known as "System Program Management". The 1970s saw the development of project management methods hampered by the constraints of the calculation barrier. It was not until the 1980s that the development of computer science together with universal access to personal computers provided a new impulse for the development of project management software (Tracki, Grucza, Ogonek, 2003).

As the economy progressed, the level of complexity of the tasks increased, which also had an impact on project management. This has become increasingly complex. There was a need to implement several projects in parallel, and this forced the transfer of project management from the unit level to the project group level. A Project Portfolio Management (PPM) strategy was created to manage processes, methods and technologies within projects implemented and simultaneously financed by the same organisation. The aim of PPM is to optimise an organisation's operational and financial goals, taking into account strategic plans, constraints imposed by customers and external factors (Parafian, 2015). The latest Project Portfolio Management structure was defined by the Project Management Institute in the form of a document in the fourth edition of ,The Standard for Portfolio Management - Fourth Edition”.

Project management methodologies, especially in a very mobile, sometimes also unpredictable, economic environment, are, on the one hand, a challenge for this environment, on the other hand, their task focuses on minimising the costs of incurred risks from a project life cycle perspective. In essence, project management methodologies are complex systems that design the predictable reality of the social and economic environment of human teams, and this boils down to the optimisation of activities in the area of task delegation, personal responsibility and motivation of employees; all of which are subordinated to the ultimate goal. Nowadays, there are many approaches to project management, and the choice depends on the matter and purpose, means and planned risks, priorities and environment. 
Agile. At present, one of the most popular methodologies is the so-called "agile project management", based on the interactions into which a project is broken up. The results of work on each interaction are continuously verified by the client. The method is based on the following principles (Cohn, 2006):

- communication with the parties is more important than using standard procedures and tools,

- focusing more on providing working solutions and less on providing detailed documentation,

- working with customers and being open to changes in scope instead of limiting them.

An event that promoted an agile approach to project management was the appearance of the agile manifesto. This methodology included the principles of the Japanese lean management method based on the tools of the Toyota production system, of which the Kaizen philosophy mentioned in this publication is part.

Scrum. Another method consistent with the agile manifesto. The project is divided into monthly iterations, called sprint runs. After each run, the project group provides the client with a working version of the sub-project for verification. The modifications introduced in the next sub-project should include a user-relevant new functionality (Chrapko, 2015).

Kanban. The word in its original meaning (in Japanese) meant an information board or signboard. The Kanban method was developed in the 1950s in Japan for production control purposes. The basic assumption of the Kanban method is to optimize the work process, which is based on information, planning, distribution and control of individual activities (Hammarberg, Sunden, 2015). Thanks to a detailed analysis of the process we realize the idea of "7 rules":

- no shortage,

- any delays,

- any stocks,

- no queues, anywhere or for anything,

- no idleness,

- no unnecessary technological and control operations,

- any migration,

The Kanban table is made of at least three parts (segments): "To do", "In progres", and "Done". You should place tasks in appropriate segments depending on their status. The Kanban table facilitates project management and allows for the detection of "bottlenecks".

Cascade Model. The cascade model (waterfall model) was defined for software engineering in the 1970s. Its functions included the implementation of subsequent design activities as separate stages, performed sequentially and cascaded (Szyjewski, 2001):

- system planning,

- $\quad$ system analysis, 
- system design,

- implementation,

- testing,

- implementation and maintenance of the system,

At each stage there was a verification, a possible product recall and a repetition of this stage until a satisfactory product was obtained at the end of the cascade.

Critical Path Method. The critical path method boils down to estimating which of the parallel sub-project task sequences will last the longest. This approach allows for the postponement or disposal of activities that may delay the implementation of a project, as the duration of the critical path determines the duration of the whole project. Each project has at least one critical path. For its calculation, mathematical methods are usually used (Grześ, 2014).

Six Sigma. This method primarily focuses on quality management by identifying and reducing manufacturing and product supervision costs (Eckes, 2011). During the entire manufacturing process of the product there are errors, or faults, which can generate excessive costs. Therefore, the aim of the method is to identify them not during the implementation of the programme, but in the planning process. Quality must not cost - this is the assumption of a method that is implemented by limiting as much as possible and, consequently, excluding and eliminating hardly tangible, seemingly unpredictable inefficiencies and behaviours that affect product performance and quality. In this method, monitoring and continuous control is based on obtaining detailed data, information, knowledge or forecasts that will multiply the predictability and effectiveness of subsequent processes and affect the chances of maintaining high quality. Projects implemented under this method must have clear objectives and continuous support from decision-makers. The above method requires key members of the project team to have knowledge of statistical methods. The project is implemented in five steps:

- the definition of,

- measurement of,

- analysis,

- improvement,

- control.

One can also see the parallelism of project management methods with those used in other areas of human activity. One such method is the concept described by the Japanese as Kaizen philosophy (kai - change, zen - good). This philosophy is a specific strategy based on continuous improvement of production processes in a company. It was originally used in Toyota. It is based on continuous small, simple improvements in subsequent, small steps. Kaizen is a way to solve small problems creatively. This is a method of preventing serious problems from becoming apparent, thanks to the ongoing removal of minor problems, since major problems are often an accumulation of problems that seem irrelevant. A company with 
a strategy of continuous small improvements adapts better to the changing environment, which is in line with a form of evolution and usually does not require significant and costly changes later on. The Kaizen's philosophy states that no company is free from specific problems, even if it is not aware of them. This assumption is a condition for implementing Kaizen. The method of small improvements, characterised by a form of synergy, often gives, after capturing all minor problems, surprising effects for a company. The method allows for the exclusion of errors and shows inconsistencies in the operation of the entire company.

Project management also requires (which should be the rule) a continuous, dynamic and creative response to small problems in order to prevent the accumulation of significant difficulties in achieving the ultimate goal. The implementation of complex projects is never free of difficult or even impossible to predict problems, which fits perfectly with Kaizen-like philosophies (Kryś, 2016).

Another area where there are parallelisms at the interface with project management is the dynamically developing field of artificial intelligence. As a field that borders many sciences, both technical and humanities, it uses methods borrowed from other fields, including project management. The following example concerns machine learning, which is part of artificial intelligence (Kaplan, 2019).

Machine learning is intended to achieve specific objectives, including:

- creating new concepts,

- detection of unknown regularities in data,

- formulation of decision-making rules,

- assimilate new concepts and structures by means of generalisations and analogies,

- to modify, generalise and specify data,

- learning by interacting with the environment,

- the formulation of knowledge understandable to man.

The general application of machine learning is, among others:

- adaptation of the system to the environment through dynamic modification, allowing for correct operation under changing conditions (robotics, control systems, production, data analysis),

- analysis, research and development of very complex problems, difficult to describe and often not having sufficient theoretical models, which are expensive, time-consuming or not very reliable (physics, mathematics).

It should be stressed that all the methods discussed boil down to the thesis put forward by ancient thinkers that project management is an art rather than technology. 


\section{Conclusion}

To sum up, project management has come a long way in human culture from the original craftsmanship, identified by the Ancients with art, to strict scientific methods using a complex mathematical apparatus. Still, however, projects are characterised by this kind of "incalculability" requiring talent and a certain amount of improvisation from managers. In order to survive in the unfavourable conditions of the natural environment, man and then the community had to adapt using his own intelligence and natural resources and later created a very functional culture that helped him to multiply his chances of survival. For at least several thousand years, man has been looking for the best and most effective strategy to develop, eliminate threats and minimise the risks associated with the uncertainty of the existing conditions of life and to take up the challenges associated with the exploratory nature of activities and undertakings in various areas of life. Project management is one of the adaptation tools that man has created and uses to achieve his goals, based on the effectiveness and dynamics of actions, but above all it is a tool that proves innovation. This innovation releases, in a broader, social dimension, the creative potential responsible for technological progress, while in the individual and organisational dimension it significantly increases the effectiveness of a group of people, e.g. the employees connected with an organisation. Project management is human nature in action.

\section{References}

1. Adamiecki, K. (1938). O istocie naukowej organizacji. Warszawa: Nakładem Koła Naukowej Organizacji Studentów PW.

2. Beliczyński, J. (2011). Praktyka $i$ wiedza z zakresu zarzadzania $w$ starożytności, https://docplayer.pl/9578840-Praktyka-i-wiedza-z-zakresu-zarzadzania-wstarozytnosci.html.

3. Chrapko, M. (2015). Scrum. O zwinnym zarzadzaniu projektami. Gliwice: Helion.

4. Cohn, M. (2006). Agile. Metodyki zwinne w planowaniu projektów. Gliwice: Helion.

5. Collinson, D. (1997). Pięćdziesięciu wielkich filozofów. Poznań: ZYSK i S-ka.

6. Diogenes Laertios (2004). Żywoty i poglądy stynnych filozofów. Warszawa: PWN.

7. Eckes, G. (2011). Six Sigma. Jako trwaty element kultury organizacji. Warszawa: MT Biznes.

8. Grześ, A. (2014), Wykres Gantta a metoda ścieżki krytycznej (CPM), https://repozytorium.uwb.edu.pl/jspui/bitstream/11320/2997/1/14_Grzes.pdf. 
9. Hammarberg, M., Sunden, J. (2015). Kanban. Zobacz jak skutecznie zarządzać praca. Gliwice: Helion.

10. Harper-Smith, P., Derry, S. (2012). Zarzadzanie projektami. Szybka droga do sukcesu. Warszawa: MT Biznes.

11. Kaplan, J. (2019). Sztuczna inteligencja. Warszawa: PWN.

12. Król, M. (2017). Skuteczne zarzadzanie projektami a kompetencje interpersonalne. Warszawa: CeDeWu Sp. z o.o.

13. Kryś, P. (2016). Kaizen w przedsiębiorstwie. https://repozytorium.uph.edu.pl/bitstream/ handle/11331/998/Krys_Kaizen_w_przedsiebiorstwie.pdf?sequence=1.

14. Maliński, J. (2015). Techne - źródło techniki. http://machinamysli.org/techne-zrodlotechniki/.

15. Małecki-Tepicht, S. (2014). O dwóch aksjologiach gospodarowania.

16. Parafian, A. Rola systemu PPM, http://www.pszw.edu.pl/images/publikacje/t074_pszw_ 2015 parafian-rola-systemu-ppm-(project-portfolio-management)-w-organizacji.pdf.

17. Pietras, P., Szmit, M. (2003). Zarzadzanie projektem, wybrane metody i techniki. Łódź: Horyzont s.c.

18. Piłatowicz, J. (ed.) (2001). Inżynierowie polscy w XIX i XX wieku. 100 najwybitniejszych polskich twórców techniki. Tom VII. Warszawa: Polskie Towarzystwo Historii Techniki, Warszawa Retro Art.

19. Platon (1999). Dialogi. Tom 1-2. Kęty: ANTYK.

20. Sobczak, R. (2017). Inżynier: wiedza, technika, technologia.

21. Sońta-Drączkowska, E. (2018). Zarządzanie projektami we wdrażaniu innowacji. Warszawa: PTE.

22. Standard for Portfolio Management (2018). Pennsylwania: Standard Management Institute.

23. Szyjewski, Z. (2001). Zarzadzanie projektami informatycznymi: metodyka tworzenia systemów informatycznych. Warszawa: Agencja wydawnicza Placet.

24. Śliwiński, R. (ed.) (2020). Strategiczne zarzadzanie projektem międzynarodowym. Warszawa: Difin.

25. Trocki, M., Grucza, B., Ogonek, K. (2003). Zarzadzanie projektami. Warszawa: PWE.

26. Walczak, R. (2020). Sukces projektu. Warszawa: CeDeWu Sp. z o.o. 